DOI 10.1007/s00417-005-0017-4

\author{
Justus G. Garweg \\ Maria Wegmann-Burns \\ David Goldblum
}

\section{Effects of daunorubicin, mitomycin C, azathioprine and cyclosporin $A$ on human retinal pigmented epithelial, corneal endothelial and conjunctival cell lines}

Received: 15 December 2004

Revised: 21 March 2005

Accepted: 15 April 2005

Published online: 10 August 2005

(C) Springer-Verlag 2005
The authors have no financial interest in this study and received no funding.

\section{J. G. Garweg $(\bowtie)$}

M. Wegmann-Burns · D. Goldblum

Department of Ophthalmology, Inselspital, University of Bern, 3010 Berne, Switzerland e-mail: justus.garweg@insel.ch Tel.: +41-31-6329565

Fax: +41-31-6328539

M. Wegmann-Burns Service d'ophtalmologie, Hôpital Cantonal de Fribourg, Fribourg, Switzerland
Abstract Background: We wished to investigate the toxicity of four immunosuppressant and antimetabolic drugs, which are known to influence postoperative wound healing, on three different human ocular cell lines. Methods: Acute toxicity to cyclosporin $\mathrm{A}$, azathioprine, mitomicyn $\mathrm{C}$ and daunorubicin was assessed in Chang cells by monitoring their uptake of propidium iodide during a 3-h period. Chronic toxicity was assessed by monitoring the proliferation and viability of subconfluent cultures of Chang cells, human corneal endothelial cells (HCECs) and retinal pigmented epithelial (RPE) cells after continuous exposure to the drugs for 7 days. Results: Acute toxicity testing revealed no obvious effects. However, the chronic toxicity tests disclosed a narrow concentration range over which cell proliferation decreased dramatically but calcein metabolism was sustained. Although the three lines reacted similarly to each agent, HCECs were the most vulnerable to daunorubicin and mitomycin. At a daunorubicin concentration of $0.05 \mu \mathrm{g} / \mathrm{ml}$, a $75 \%$ decrease in calcein metabolism $(P<0.001)$ and a $\geq 95 \%$ cell loss $(P<0.001)$ were observed. At a mitomycin concentration of $0.01 \mu \mathrm{g} / \mathrm{ml}$, cell density decreased by $61 \%$
$(P<0.001)$ without a change in calcein metabolism, but at $0.1 \mu \mathrm{g} / \mathrm{ml}$, the latter parameter decreased to $12 \%$ $(P=0.00014)$. At this concentration the proliferation of Chang and RPE cells decreased by more than $50 \%$, whilst calcein metabolism was largely sustained. Cyclosporin inhibited cell proliferation moderately at lower concentrations $(<5 \mu \mathrm{g} / \mathrm{ml} ; P=0.05)$ and substantially at higher ones, with a corresponding decline in calcein metabolism. Azathioprine induced a profound decrease in both parameters at concentrations above $5 \mu \mathrm{g} / \mathrm{ml}$. Conclusion: Daunorubicin, cyclosporin and azathioprine could be used to inhibit excessive intraocular scarring after glaucoma and vitreoretinal surgery without overly reducing cell viability. The attributes of immunosuppressants lie in their combined antiproliferative and immunomodulatory effects.

Keywords Wound healing · Cyclosporin A · Azathioprine . Mitomycin - Daunorubicin - Toxicity · Cell-viability assay $\cdot$ Calcein uptake Cell proliferation $\cdot$ Chang cells . Retinal pigmented epithelial cells . Human corneal endothelial cells .

PVR · Glaucoma 


\section{Introduction}

The control of wound healing after intraocular surgery is important for the long-term outcome. Numerous antiproliferative agents (e.g. cytostatics) have been tested for their ability to inhibit scar formation after fistulating glaucoma $[16,21,25]$ and vitreoretinal surgery $[4,30]$.

Today, the drugs of choice in glaucoma surgery are 5fluorouracil and mitomycin C. However, neither the optimal mode of application (intraoperatively or during the early postoperative course) nor the concentration with the best risk-benefit ratio has been clearly established, which may have contributed to the unpredictable antiproliferative effects reported $[1,7,20]$.

The capacity of several anti-inflammatory, antiproliferative and cytotoxic agents to reduce cell proliferation in association with proliferative vitreoretinopathy (PVR) has also been investigated. The intravitreal use of long-acting steroids and steroid-containing drug-delivery systems has been reported to improve the postoperative course following retinal detachment surgery $[2,11,24]$. However, only a few locally applied antiproliferative drugs, such as daunorubicin, mitomycin and 5-fluorouracil, have so far revealed sufficiently promising results in the experimental setting to justify clinical testing $[4,9,18,29]$. To date, only systemic corticosteroids are used postoperatively on a standard basis. None of the other agents investigated has been broadly applied, owing to their retinotoxicity and other side-effects.

In the present study we investigated the effects of four established antiproliferative and immunosuppressive drugs (daunorubicin, mitomycin $\mathrm{C}$, azathioprine and cyclosporin A) on the proliferation and metabolism of three different lines of human ocular cells [Chang, retinal pigmented epithelial (RPE) and human corneal endothelial cells (HC ECs)], which could be exposed to these agents after local application.

\section{Materials and methods}

\section{Cell cultures}

Immortalized HCECs had kindly been provided by Prof. K. Engelmann (University of Dresden) and Dr. J. Bednarz (University of Hamburg). Corneo-endothelial cells were used because any antimitotic agent being used in glaucoma surgery might diffuse into the anterior chamber and thereby expose the postmitotic corneal endothelium to its toxic effects. These would thus be deleterious to corneal clarity.

Human RPE cells were collected from several tissue donors and cultured in vitro. Cells derived from passages 3-5 were used for proliferation and metabolism assays in order to prevent the functional modifications that might possibly occur at a later stage of culturing.

Human transfected conjunctival Chang P12 cells were purchased from ECACC (Salisbury, England).
Each cell line was cultured in MEM (Gibco/Invitrogen Life Technologies, Basle, Switzerland), which was enriched with $10 \%$ foetal bovine serum (Gibco) and supplemented with L-glutamine $(2 \mathrm{mM})$, penicillin $(10,000 \mathrm{U} / \mathrm{ml})$, streptomycin $(10,000 \mu \mathrm{g} / \mathrm{ml})$ and amphotericin B $(25 \mu \mathrm{g} /$ $\mathrm{ml})$. The cultures were maintained at $32^{\circ} \mathrm{C}$ in a humidified atmosphere containing $5 \% \mathrm{CO}_{2}$ until they had attained subconfluence.

\section{Drugs and experimental set-up}

For acute toxicity tests, only the Chang cell line was used. Each of the four drugs was tested at concentrations of 10 , 50 and $100 \mu \mathrm{g} / \mathrm{ml}$.

For chronic toxicity tests, each of the three cell lines was used, with drug concentrations of $0.01-50 \mu \mathrm{g} / \mathrm{ml}$ being investigated. In the absence of other existing data the chosen concentrations reflect the doses used clinically. Consequently, they lie well below the expected acute toxic levels for antimetabolites and immunosuppressants.

Cyclosporin A (Fluka, Buchs, Switzerland) was dissolved in 99\% ethanol (Hospital Pharmacy, Inselspital Bern, Switzerland) to a final concentration of $10 \mathrm{mg} / \mathrm{ml}$. It was further diluted in $50 \%$ ethanol to yield a concentration of $1 \mathrm{mg} / \mathrm{ml}$ and in $2.5 \%$ ethanol to yield one of $100 \mu \mathrm{g} / \mathrm{ml}$, in accordance with the manufacturer's instructions.

Azathioprine (Sigma/Fluka, Buchs, Switzerland) was first diluted in $1 \mathrm{M} \mathrm{NH}_{3}$ (Merck, Dietikon, Switzerland), to yield a concentration of $10 \mathrm{mg} / \mathrm{ml}$, then passed through a sterile filter [with a pore size of $25 \mu \mathrm{m}$ (Millipore, Bedford, Mass., USA)], subsequently diluted in distilled water, and finally filtered again.

Mitomycin C (Kyowa, Tokyo, Japan) and daunorubicin (Fluka) were dissolved in distilled water to provide a stock solution of $2 \mathrm{mg} / \mathrm{ml}$. These solutions were further diluted in distilled water to provide the appropriate concentrations and were then filtered under sterile conditions.

For the acute toxicity tests, Chang cells were seeded onto 24-well Costar culture plates at a density of 6,000 cells/ well. For chronic toxicity tests, cells of each line were seeded at a density of 1,500 cells/well and then grown to subconfluence overnight, before the experiments were begun. Each experimental condition was tested six times in parallel. A negative control (using the same diluents as for the tested drugs) was included in all instances.

\section{Acute toxicity tests}

Acute toxicity tests were run only on Chang cells, an ocular fibroblast line. Little additional information was expected from acute toxicity testing on the other cell lines, since the drug concentrations, having been chosen with a view to clinical application, lay below the expected acute toxicity levels. Furthermore, experiments for chronic toxicity re- 
vealed no marked differences between the analysed cell lines at the tested drug concentrations.

Acute toxicity was assessed by the propidium-iodide assay. Propidium iodide enters non-viable cells and binds irreversibly to their nuclei, whereupon it acts as a fluorescent dye. The amount of bound propidium iodide was quantified by measurement of the fluorescence in a Cytofluor (Millipore), using an excitation/emission wavelengthcoupling of 530/645 nm [28].

For this purpose, cell monolayers were incubated with $1 \mathrm{ml}$ of serum-free MEM containing propidium iodide $(20 \mu \mathrm{g} / \mathrm{ml})$ and the drug to be tested. Fluorescence was measured every 15 min during the first hour and every $30 \mathrm{~min}$ during the following $3 \mathrm{~h}$. The cells were then incubated for $1 \mathrm{~h}$ with $1 \mathrm{ml}$ of $1.5 \%$ Tween 20 (Gibco/ Invitrogen Life Technologies) to permeabilize the cell membranes and yield the (maximal) endpoint fluorescence. Toxicity was expressed as the quotient of the experimental fluorescence (for each drug and concentration) and the endpoint fluorescence.

Chronic toxicity tests

Chronic toxicity was assessed by the decreases in cellesterase activity and cell growth after 7 days of continuous exposure to the test drug. The drug-containing culture me- dium was changed after 4 days. Seven days represents the maximum time-span elapsing before cell overgrowth renders counting very difficult and imprecise. This time-span is also reasonable from a clinical viewpoint, since it corresponds to the critical period of postsurgical wound healing, i.e. that which determines the ultimate success or failure of an operation.

Cell-esterase activity and cell-viability testing

Calcein-AM (Molecular Probes Europe, Leiden, Netherlands), a fluorogenic esterase substrate, is converted intracellularly by a cytoplasmic esterase. Calcein is a membrane-impermeable green fluorescent dye, which is retained only by viable cells. It was quantified by measurement of the fluorescence emitted at $485 \mathrm{~nm}$ in a Cytofluor (Millipore).

Cell monolayers were gently washed in phosphatebuffered saline (PBS) and then incubated with $200 \mu$ of MEM (without phenol red), containing $1.5 \mu \mathrm{M}$ calcein$\mathrm{AM}$, for $30 \mathrm{~min}$. They were then carefully rinsed twice and covered with $500 \mu \mathrm{l}$ of MEM (without phenol red) for the fluorescent measurement of calcein uptake and activation. Following this measurement, the supernatant containing dead, unattached cells was discarded. The monolayers of living cells were then gently washed, trypsinized and harvested. The numerical density of cells was determined with
Fig. 1 a Proliferation assay with daunorubicin. The numerical density of the three cell lines measured after 7 days of incubation with various concentrations is expressed as a percentage of the density obtained without the drug. Values represent the mean $( \pm \mathrm{SD})$ of the six experiments. ${ }^{*} P<0.05$. b Calcein-AM assay for chronic toxicity with daunorubicin. The esterase activity of the three cell lines after incubation with various concentrations for 7 days is shown as a percentage of the maximal fluorescence (incubation without drug). All values are the mean $( \pm$ SD) of the six experiments. $* P<0.05$ a

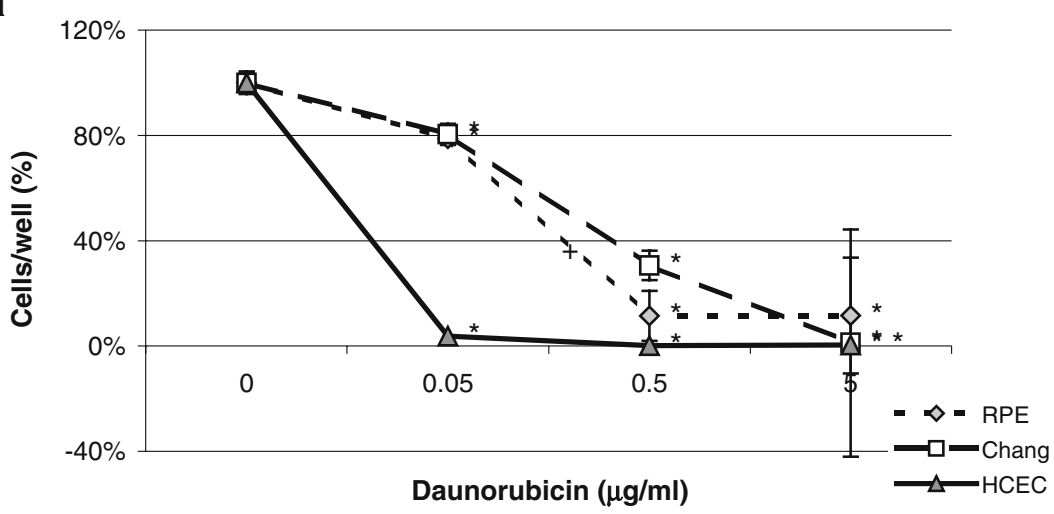

b

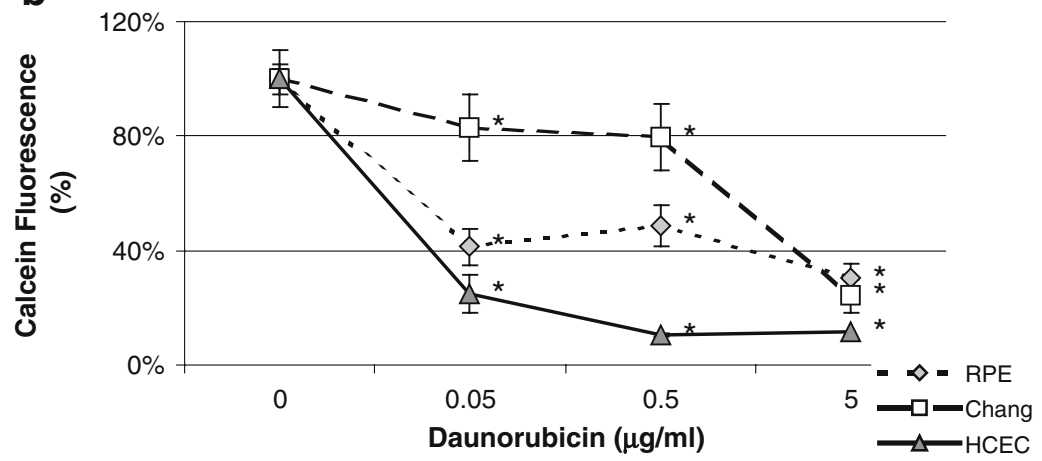


a cell counter calibrated for this purpose (Sysmex Europe, Chronic toxicity

Norderstedt, Germany).

The chronic toxicity of the four agents was assessed in each of the three cell lines by the monitoring of proliferation

\section{Statistical evaluation}

Data presented represent the average of six experiments in each group. Fluorescence measurements and cell counts were compared statistically by the application of Student's $t$-test, using Bonferroni's correction to highlight significant differences $(P<0.05)$ between the values.

\section{Results}

\section{Acute toxicity}

Acute toxicity testing of the four agents on Chang cells revealed few or no deleterious effects within the clinically relevant concentration range. At a concentration of, or above, $50 \mu \mathrm{g} / \mathrm{ml}$, cyclosporin A elicited an increase in cell death after an exposure time of $90 \mathrm{~min}$. Neither azathioprine nor mitomycin $\mathrm{C}$ induced a cytotoxic effect at any time during the experimental time course or at any of the tested concentrations. Daunorubicin was similarly impotent in the concentration range $0.1-10 \mu \mathrm{g} / \mathrm{ml}$ (data not shown). (cell count) and calcein metabolism after 7 days of continuous exposure.

\section{Daunorubicin}

HCECs were the most vulnerable of the three cell lines. At a concentration of $0.05 \mu \mathrm{g} / \mathrm{ml}$, daunorubicin elicited a decrease in calcein metabolism of $75 \%(P=0.000079)$ and a cell loss of more than $95 \%(P=0.000079)$. In the RPE and Chang cell lines these parameters underwent a less pronounced decline at a drug concentration of $0.5 \mu \mathrm{g} / \mathrm{ml}$, with cell density being more susceptible than calcein metabolism (Fig. 1).

\section{Mitomycin C}

As with daunorubicin, HCECs were the most vulnerable of the three cell lines. At a mitomycin concentration of $0.01 \mu \mathrm{g} / \mathrm{ml}$, cell density decreased by $61 \%(P=0.000079)$, whereas calcein metabolism was still above $80 \%$. Howev-
Fig. 2 a Proliferation assay with mitomycin. The numerical density of the three cell lines measured after 7 days of incubation with various concentrations is expressed as a percentage of the density obtained without the drug. Values represent the mean $( \pm$ SD) of the six experiments. ${ }^{*} P<0.05$. b Calcein-AM assay for chronic toxicity with mitomycin. The esterase activity of the three cell lines after incubation with various concentrations for 7 days is shown as a percentage of the maximal fluorescence (incubation without drug). All values are the mean $( \pm \mathrm{SD})$ of the six experiments. $* P<0.05$

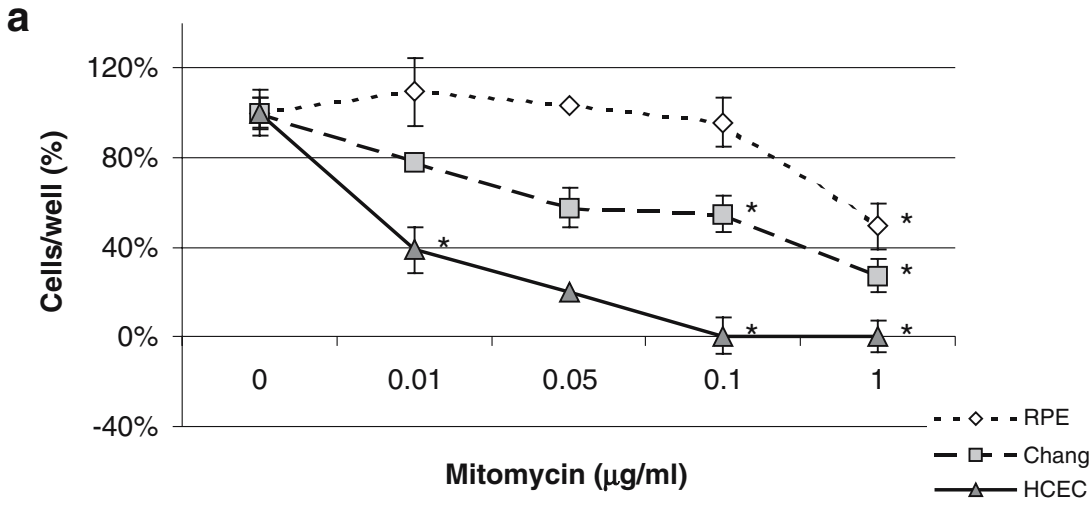

b

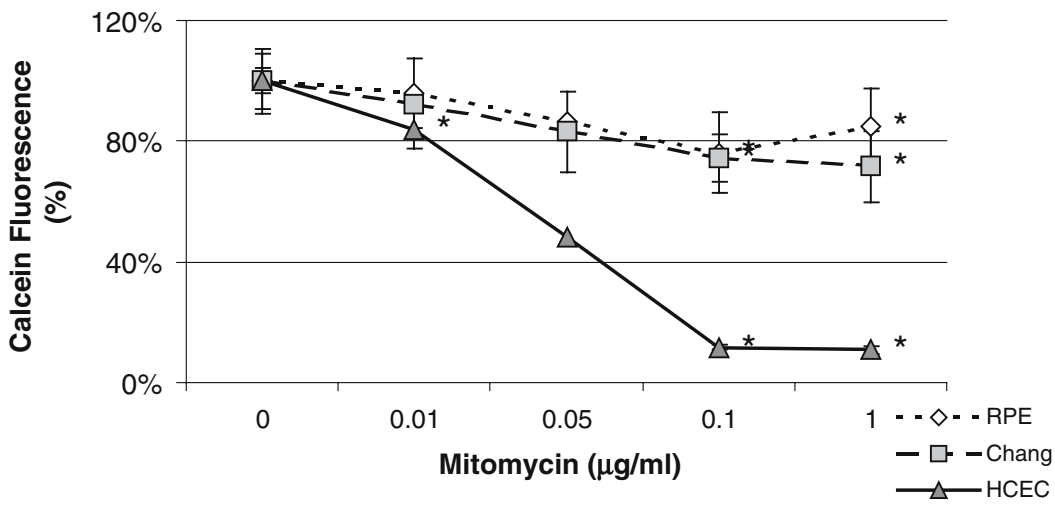


Fig. 3 a Proliferation assay with cyclosporin A. The numerical density of the three cell lines measured after 7 days of incubation with various concentrations is expressed as a percentage of the density obtained without the drug. Values represent the mean $( \pm \mathrm{SD})$ of the six experiments. ${ }^{*} P<0.05$. b Calcein-AM assay for chronic toxicity with cyclosporin A. The esterase activity of the three cell lines after incubation with various concentrations for 7 days is shown as a percentage of the maximal fluorescence (incubation without drug). All values are the mean $( \pm \mathrm{SD})$ of the six experiments. ${ }^{*} P<0.05$
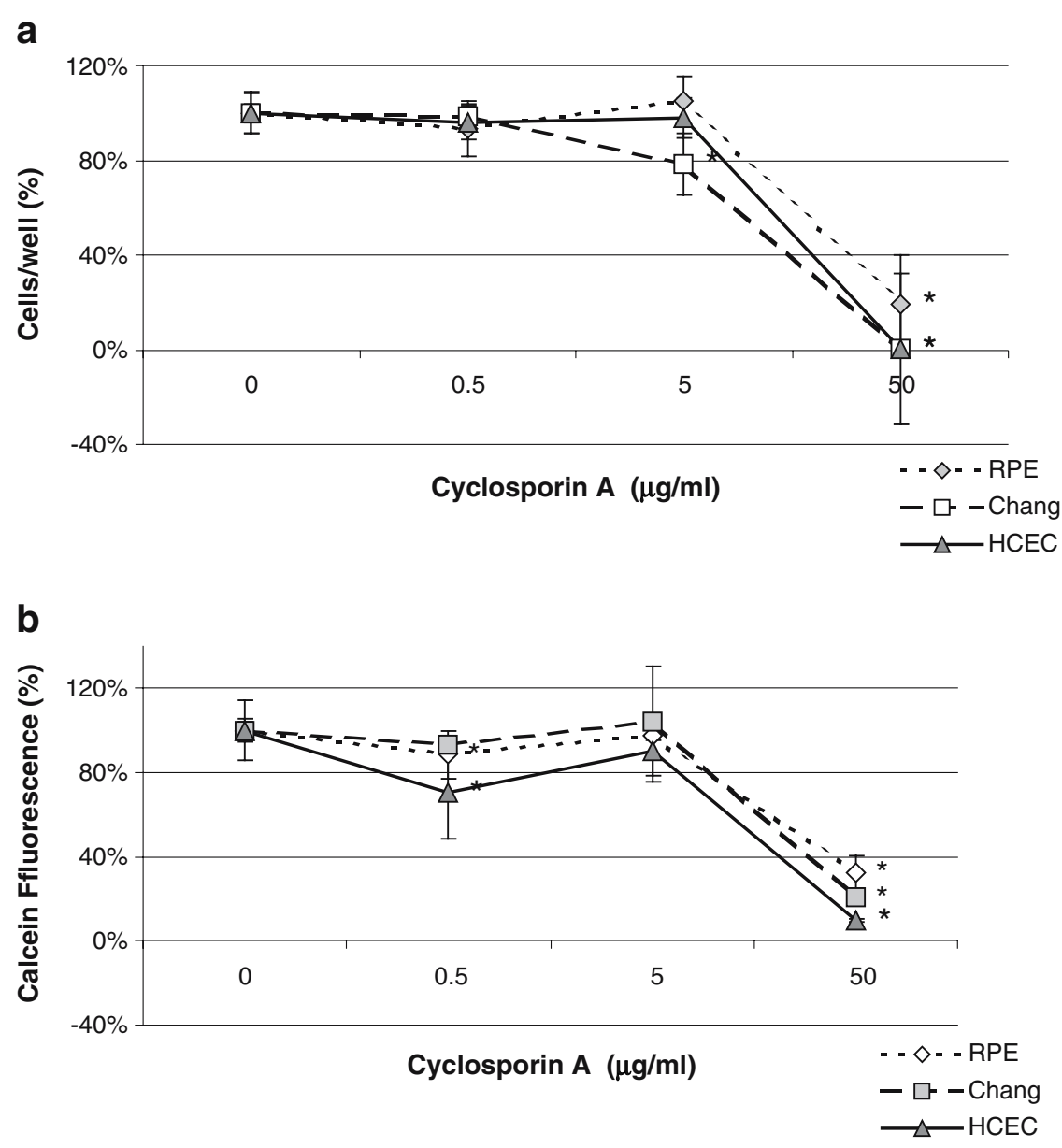

er, when the mitomycin concentration was raised to $0.1 \mu \mathrm{g} /$ $\mathrm{ml}$, the latter parameter dropped to $12 \%(P=0.00014)$.

Above concentrations of $0.05 \mu \mathrm{g} / \mathrm{ml}$ and $0.1 \mu \mathrm{g} / \mathrm{ml}$, the density of Chang and RPE cells decreased by more than $70 \%$ and $50 \%$, respectively, whereas calcein metabolism was largely unaffected [although the differences were statistically significant: for Chang cells, $P=0.0172$; for RPE cells, $P=0.0136$ (Fig. 2)].

\section{Cyclosporin A}

All three cell lines responded similarly to cyclosporin A. At concentrations below $5 \mu \mathrm{g} / \mathrm{ml}$ this drug did not inhibit cell proliferation significantly $(P=0.05)$, whereas above $5 \mu \mathrm{g} /$ $\mathrm{ml}$, a substantial reduction in this parameter was observed. At $50 \mu \mathrm{g} / \mathrm{ml}$ cell proliferation in each of the cell lines was inhibited by more than $80 \%$. In the RPE cells and HCECs, changes in calcein metabolism corresponded to those in cell density. Interestingly, calcein metabolism in the Chang cells was still unaffected at a cyclosporin concentration of $5 \mu \mathrm{g} / \mathrm{ml}$, whereas cell proliferation had already decreased by more than $20 \%(P=0.005)$. However, at concentrations above $5 \mu \mathrm{g} / \mathrm{ml}$, both cell proliferation and cell metabolism underwent a substantial decline (Fig. 3).

Azathioprine

For HCECs and Chang cells the azathioprine-induced changes in cell proliferation and calcein metabolism were similar, with both parameters decreasing sharply at concentrations above $5 \mu \mathrm{g} / \mathrm{ml}$. At $50 \mu \mathrm{g} / \mathrm{ml}$, Chang cell proliferation tended to be inhibited more markedly than calcein metabolism (Fig. 4).

At a drug concentration of $5 \mu \mathrm{g} / \mathrm{ml}$, calcein metabolism in RPE cells decreased significantly without a decline in cell proliferation. However, at concentrations above $5 \mu \mathrm{g} / \mathrm{ml}$, both calcein metabolism and cell proliferation were substantially inhibited.

\section{Discussion}

Our findings reveal that the proliferation and metabolism of ocular cell lines may respond independently to toxic 
Fig. 4 a Proliferation assay with azathioprine. The numerical density of the three cell lines measured after 7 days of incubation with various concentrations is expressed as a percentage of the density obtained without the drug. Values represent the mean $( \pm \mathrm{SD})$ of the six experiments. ${ }^{*} P<0.05$. b Calcein-AM assay for chronic toxicity with azathioprine. The esterase activity of the three cell lines after incubation with various concentrations for 7 days is shown as a percentage of the maximal fluorescence (incubation without drug). All values are the mean $( \pm \mathrm{SD})$ of the six experiments. $* P<0.05$
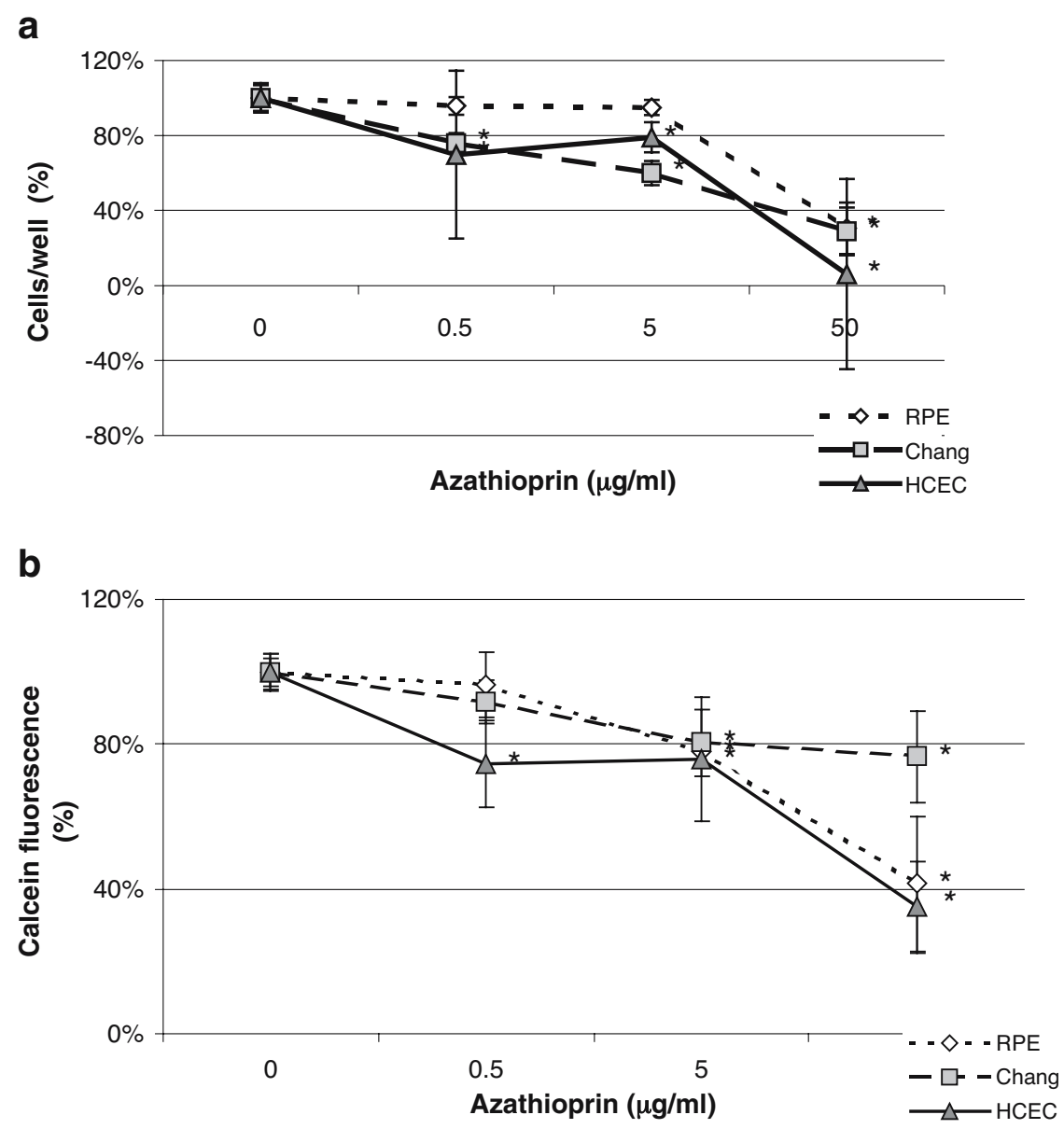

influences, the former being more susceptible (occurring at lower concentrations) than the latter. For each of the agents tested, HCECs were more vulnerable than either the RPE or Chang lines. Our data also suggest that the immunomodulatory drug cyclosporin A may be a suitable candidate for the control of wound healing. Apart from having a direct impact on cell proliferation, this drug is also capable of modulating the postoperative inflammatory tissue reaction and, thus, of controlling wound healing.

Acute toxicity testing revealed no significant effects of any of the agents, even at concentrations of up to $100 \mu \mathrm{g} /$ $\mathrm{ml}$. Hence, the chosen doses met our expectations for acute subthreshold cytotoxic levels. These findings correspond to those reported by other investigators. For example, at mitomycin concentrations up to $10 \mu \mathrm{g} / \mathrm{ml}$, even fibroblasts retained their ability to proliferate [7]. In addition, over the same range, cyclosporin A similarly failed to inhibit the proliferation of human conjunctival fibroblasts [10].

Mitomycin $\mathrm{C}$ has already been shown to efficiently inhibit postoperative scarring in high-failure-risk patients who have undergone glaucoma surgery $[3,7]$. In addition, after photokeratectomy with the excimer laser [19, 23], a dose-dependent inhibition of fibroblast proliferation has been reported for this drug. However, the efficacy of mitomycin in preventing scarring after trabeculectomy is compromised by the high rate of complications, such as persistent hypotony, thin avascular cystic blebs and endophthalmitis $[12,22]$. In refractive surgery, local side-effects, such as superficial punctuate keratopathy, recurrent corneal epithelial defects, iridocyclitis and scleral melting, have been observed [17]. In our study, the proliferation of HCECs was highly susceptible to mitomycin. At a drug concentration of only $0.01 \mu \mathrm{g} / \mathrm{ml}$, this parameter decreased by $61 \%$. On the other hand, calcein metabolism was still above $80 \%$ at this concentration, thereby indicating a possible therapeutic window. In glaucoma surgery, mitomycin concentrations between $0.1 \mathrm{mg} / \mathrm{ml}$ and $0.5 \mathrm{mg} / \mathrm{ml}$ are most commonly used but with variations in application time and the mode of application $[1,3,8,13]$. On the basis of our findings, a concentration of $1.0 \mu \mathrm{g} / \mathrm{ml}$ would be suitable to prevent the proliferation of RPE cells and PVR without untoward toxic effects.

Cyclosporin A inhibited proliferation in each of the three cell lines at concentrations of up to $5 \mu \mathrm{g} / \mathrm{ml}$, which had no profound effect on cell metabolism. At $5 \mu \mathrm{g} / \mathrm{ml}$, the density of Chang cells decreased significantly $(>20 \%)$, whereas 
calcein metabolism was not affected. In vivo studies support the use of topical $2 \%$ cyclosporin in trabeculectomy surgery, the control of intraocular pressure being comparable to that achieved with mitomycin C [27]. Together with preliminary clinical evidence, our findings justify a continued search for other immunosuppressants with a greater capacity to inhibit cell proliferation but with a correspondingly acceptable cell-toxicity profile. However, several recent studies indicate that the inhibition of cell proliferation alone may not suffice to hinder postoperative scarring, since growth-arrested fibroblasts can still influence this process - either directly or indirectly - via the production of regulatory proteins $[5,16]$. The use of immunosuppressants rather than antiproliferative cytotoxic agents (either alone or adjunctively) $[6,15,26]$ could be advantageous in this respect, owing to their combined antiproliferative and immunomodulatory effects [31].

Due to their unphysiological $\mathrm{pH}$ values, preparations of azathioprine have not been applied to control ocular wound healing in vivo. In the present study, this drug inhibited cell proliferation more profoundly than calcein metabolism in HCECs and Chang cells at a concentration of $50 \mu \mathrm{g} / \mathrm{ml}$.

For each of the four agents tested there existed a narrow concentration range over which cell proliferation was inhibited substantially without a marked reduction in calcein metabolism, which is a desirable effect for a drug applied immediately after glaucoma and retinal surgery (i.e., during the wound-healing phase). Critics might question the validity of this test result, arguing that a reduction in calcein metabolism is the sum of proliferation inhibition and cell toxicity. However, other studies have shown that calcein metabolism does not decrease in direct proportion to the decline in cell number, especially near the IC-50 range (i.e., that at which $50 \%$ of the cells are inhibited), where calcein metabolism peaks before decreasing sharply. This phenomenon has been attributed to a selective activation of ion channels in the surviving cell population [32]. Nevertheless, other metabolic functions of cultured cells should now be assessed to validate the surprisingly narrow therapeutic window observed in our study, experience having taught us that the window is equally narrow in the clinical setting.

To the best of our knowledge no previous study has directly compared the effects of more than one antiproliferative agent on three different human cell lines, and our data may thus be more applicable to the clinical setting than those emanating from non-human cell experiments. Furthermore, we assessed the potential benefits of the antiproliferative agents in terms not only of their dose-dependent effects on cell proliferation but also of their metabolic effects on the surviving cell population. In this latter context, cytoplasmic esterase activity is deemed to be a representative marker [14, 32].

An in vitro assessment of cell proliferation and viability permits a preselection of the most promising drugs. Only these need to be tested in animal experiments, the number of which can thus be drastically reduced. Nevertheless, there is no way that any drug tested in vitro could then be used in humans without previous extensive animal testing, though the in vitro studies may set the stage for the dimensions of animal testing.

A drawback of our study was the limited concentration range of the drugs tested. For this reason, it was not possible to calculate the IC-50 values. Similarly, we were unable to establish the drug concentration at which toxic effects began after only a short exposure time (acute toxicity testing).

In summary, our results indicate that cyclosporin A, azathioprine and daunorubicin may represent a group of substances that could be employed, either alone or in combination, to optimize the wound-healing process after glaucoma or vitreoretinal surgery by inhibiting excessive scarring without overly reducing cell viability. However, in vivo studies are now required to optimize the drug dose as well as the mode and duration of application. The search for other pharmacological agents, that are capable of controlling the postoperative scarring response and, ideally, also the postoperative inflammatory tissue response without unsupportable adverse complications in these surgical settings, should continue.

\section{References}

1. Ben-Simon GJ, Glovinsky Y (2003) Needle revision of failed filtering blebs augmented with subconjunctival injection of mitomycin C. Ophthalmic Surg Lasers 34:94-99
2. Berger AS, Cheng CK, Pearson A, Ashton P, Crooks PA, Cynkowski T, Cynkowska G, Jaffe GJ (1996) Intravitreal sustained release corticosteroid-5fluorouracil conjugate in the treatment of experimental proliferative vitreoretinopathy. Investig Ophthalmol Vis Sci 37:2318-2325

3. Bindlish R, Condon GP, Schlosser JD, D'Antonio J, Lauer KB, Lehrer R (2002) Efficacy and safety of mitomycin-C in primary trabeculectomy. Ophthalmology 109:1336-1341
4. Blumenkranz M, Hernandez E, Ophir A, Norton EWD (1984) 5-Fluorouracil: new applications in complicated retinal detachment for an established antimetabolite. Ophthalmology 91:122-129

5. Daniels JT, Occleston NL, Crowston JG, Khaw PT (1999) Effects of antimetabolite induced cellular growth arrest on fibroblast-fibroblast interactions. Exp Eye Res 69:117-127 
6. Hui YN, Liang HC, Cai AS, KirchhofB, Heidemann K (1993) Corticosteroids and daunomycin in the prevention of experimental proliferative vitreoretinopathy induced by macrophages. Graefe Arch Clin Exp Ophthalmol 231:109114

7. Khaw PT, Sherwood MB, MacKay SL, Rossi MJ, Schultz G (1992) Five-minute treatments with fluorouracil, floxuridine, and mitomycin have long-term effects on human Tenon's capsule fibroblasts. Arch Ophthalmol 110:11501154

8. Khaw PT, Doyle JW, Sherwood MB, Grierson I, Schultz G, McGorray S (1993) Prolonged localized tissue effects from 5-minute exposures to fluorouracil and mitomycin C. Arch Ophthalmol 111:263-267

9. Khawly JA, Saloupis P, Hatchell DL, Machemer R (1991) Daunorubicin treatment in a refined experimental model of proliferative vitreoretinopathy. Graefe Arch Clin Exp Ophthalmol 229:464-467

10. Leonardi A, DeFranchis G, Fregona IA, Violato D, Plebani M, Secchi AG (2001) Effects of cyclosporin A on human conjunctival fibroblasts. Arch Ophthalmol 10:1512-1517

11. Machemer R, Sugita G, Tano Y (1979) Treatment of intraocular proliferations with intravitreal steroids. Trans Am Ophthalmol Soc 77:171-180

12. Mandal AK, Bagga H, Nutheti R, Gothwal VK, Nanda AK (2003) Trabeculectomy with or without mitomycin-C for paediatric glaucoma in aphakia and pseudophakia following congenital cataract surgery. Eye 17:53-62

13. Mietz H, Jacobi PC, Krieglstein GK (2002) Intraoperative episcleral versus postoperative topical application of mitomycin $\mathrm{C}$ for trabeculectomies. Ophthalmology 109:1343-1349
14. Neri S, Mariani E, Meneghetti A, Cattini L, Facchini A (2001) Calcein-acetyoxymethyl cytotoxicity assay: standardization of a method allowing additional analyses on recovered effector cells and supernatants. Clin Diagn Lab Immunol 8:1131-1135

15. Nuzzi R, Cerruti A, Finazzo C (1998) Cyclosporine C: a study of woundhealing modulation after trabeculectomy in rabbit. Acta Ophthalmol Scand Suppl 227:48-49

16. Occlston NL, Daniels JT, Tarnuzzer RW, Sethi KK, Alexander RA, Bhattacharya SS, Schultz GS, Khaw PT (1997) Single exposures to antiproliferatives. Investig Ophthalmol Vis Sci 38:1998-2007

17. Rubinfeld RS, Pfister RR, Stein RM (1992) Serious complications of topical mitomycin- $\mathrm{C}$ after pterygium surgery. Ophthalmology 99:1647-1654

18. Salah-Eldin M, Peyman GA, El-Aswad M, Bandok G, Bahgat MM, Niesman MR (1994) Evaluation of toxicity and efficacy of antineoplastic agents in the prevention of PVR. Int Ophthalmol 18:53-60

19. Schipper I, Suppelt C, Gebbers JO (1997) Mitomycin C reduces scar formation after excimer laser (193 nm) photorefractive keratectomy in rabbits. Eye 11:649-655

20. Shin DH, Kim YY, Ginda SY, Kim PH, Eliassi-Rad B, Khatana AK, Keole NS (2001) Risk factors for failure of 5fluorouracil needling revision for failed conjunctival filtration blebs. Am J Ophthalmol 132:875-880

21. Shin DH, Iskander NG, Ahee JA, Singal IP, Kim C, Hughes GA, Eliassi-Rad B, Kim YY (2002) Long-term filtration and visual field outcomes after primary glaucoma triple procedure with and without mitomycin-C. Ophthalmology 109:1607-1611

22. Suñer IJ, Greenfield DS, Miller MP, Nicolela MT, Palmberg PF (1997) Hypotony maculopathy after filtering surgery with mitomycin C. Ophthalmology 104:207-214

23. Talamo JH, Gollamundi S, Green WR (1991) Modulation of corneal wound healing after excimer laser keratomileusis using topical mitomycin $\mathrm{C}$ and steroids. Arch Ophthalmol 109:11411146
24. Tano Y, Sugita G, Abrams G, Machemer R (1989) Inhibition of intraocular proliferation with intravitreal corticosteroids. Am J Ophthalmol 89:131-136

25. The Fluorouracil Filtering Surgery Study Group (1989) Fluorouracil filtering surgery study one-year follow-up. Am J Ophthalmol 108:625-635

26. Tung IC, Wu WC, Kao YH, Chang YC, Chung CH, Hu DN (2001) The effect of combined 5-fluorouracil and dexamethasone on cultured human retinal pigment epithelial cells. Kaohsiung J Med Sci 17:524-529

27. Turaçli E, Gündüz K, Aktan G, Tamer C (1996) A comparative clinical trial of mitomycin $\mathrm{C}$ and cyclosporin $\mathrm{A}$ in trabeculectomy. Eur J Ophthalmol 6:398-401

28. Ventura AC, Böhnke M (1999) Toxicity of pentoxifylline on monolayers of highly proliferative cells of epithelial origin. J Ocul Pharmacol Ther 15:525535

29. Wiedemann P, Lemmen K, Schmiedl R, Heimann K (1987) Intraocular daunorubicin for the treatment and prophylaxis of traumatic proliferative vitreoretinopathy. Am J Ophthalmol 104:10-14

30. Wiedemann P, Hilgers RD, Bauer P, Heimann K (1998) Adjunctive daunorubicin in the treatment of proliferative vitreoretinopathy: results of a multicenter clinical trial. Am J Ophthalmol 126:550-559

31. Wu WC, Kao YH, Hu DN (2002) A comparative study of effects of antiproliferative drugs on human retinal pigment epithelial cells in vitro. J Ocul Pharmacol Ther 18:251-264

32. Yang A, Cardona DL, Barile FA (2002) In vitro cytotoxicity testing with fluorescence-based assays in cultured human lung and dermal cells. Cell Biol Toxicol 18:97-108 